2 Proceedings of the Second Annual Forestry Symposium 1996: Management and Sustainable Utilization of Forest Resources, Sri Lanka, 6-7 December 1996. (Eds. Amarasekera, HS, Ranasinghe, D M S HK and Finlayson, $W$. Published by Department of Forestry and Environmental Science, University of Sri Jayewardenepura, Sri Lanka (1998)

\title{
ATTACK BY WOOD-DESTROYING INSECTS ON EIGHT COMMERCIAL TIMBER SPECIES
}

\author{
N. Shilpa De Silva and H.S. Amarasekara \\ Department of Forestry and Environmental Science. \\ University of Sri Jayewardenepura
}

\begin{abstract}
The relative susceptibility of the heartwood of eight species was studied by exposing them to a subterranean termite, the powder-post beetle, and the longhorn beetle. Both graveyard tests and laboratory methods were used. Observations were made on the weight loss of the timber and on the mortality of the insects. The data were subjected to analysis of variance, and means significantly different at the 5\% level were separated by Tukey's test. Finally, the timber species were ranked for resistance to insect attack. The most resistance species were Eucalyptua grandis; teak and jak, followed by Pinus caribaea, lumumidella and mahogany. Rubber was the most susceptible species. Tualang timber was unplaced in the overall ranking, because it was omitted from one test, but it would come near the top.
\end{abstract}

\section{Introduction}

As Sri Lanka is a tropical country. loss of wood due to insect attack is relatively high. A subterranean termite, Odontotermes redemanni, the powder-post beetle, Heterobostrychus brunneus, and the longhom beetle, Batocera rubus, are known to be major wood destroying insects here (De Silva and Amarasckara, 1996). Of these three insects, the termite is an important pest and it is difficult to find timber species completely immune to its attack. It works inside the timber along the grain, eating out large galleries or runways. The powderpost beetle is also an active and destructive pest; it attacks logs, sawn timber, furniture and buildings. The larvae of the longhorn beetle do serious damage by tumnelling in the heartwood of logs after felling; it is a serious pest in the Moratuwa area. This paper records an attempt to study the attack of these three insects, and to rank the timber species tested according to loss of weight when attacked.

\section{Materials and methods}

Insects of the three species mentioned above were collected from infected timber in the Moratuwa area. Specimens of eight commercial timber species: jak (Artocarpus heterophyllus), eucalypt (Eucalyptus grandis), rubber (Hevea brasiliensis), tualang (Koompassia excelsa), lunumidella (Melia dubia). pine (Pinus caribaea), mahogany 
(Sivietenia macrophylla), and teak (Tectona grandis) were collected from timber stores and log yards in the same area and used throughout the experiments.

\section{Attack by subterranean termites in the ficld}

Graveyard tests were carried out at the field centre of the University of Sri Jayewardenepura and in a home garden in Udammita in the wet zone, for a period of six months. The plot size was $8 \times 3.5$ feet $(2.44 \times 1.07 \mathrm{~m})$. One foot depth $(30 \mathrm{~cm})$ of soil was removed and replaced by mould from termites (of the same species), tamped doun firmly. Stakes of $50 \times 5 \times 2.5$ $\mathrm{cm}$, of the heartwood of each species, were oven dried at $105^{\circ} \mathrm{C}$ and put in position (Figure 1). The site was watered in the early stages to help in the formation of colonies (Eaton and Hale, 1993; Gay et al 1957). The percentage weight losses were recorded as:

Where:

$$
\text { Percent weight loss }=\left[\left(\mathrm{W}_{1}-\mathrm{W}_{2}\right) / \mathrm{W}_{\mathrm{d}} \mathrm{d} \times 100\right.
$$

$$
\begin{aligned}
& \mathrm{W}_{1}=\text { initial weight of the stake } \\
& \mathrm{W}_{2}=\text { weight after attack } \\
& \mathrm{W}_{\mathrm{d}}=\text { oven-dried weight }
\end{aligned}
$$

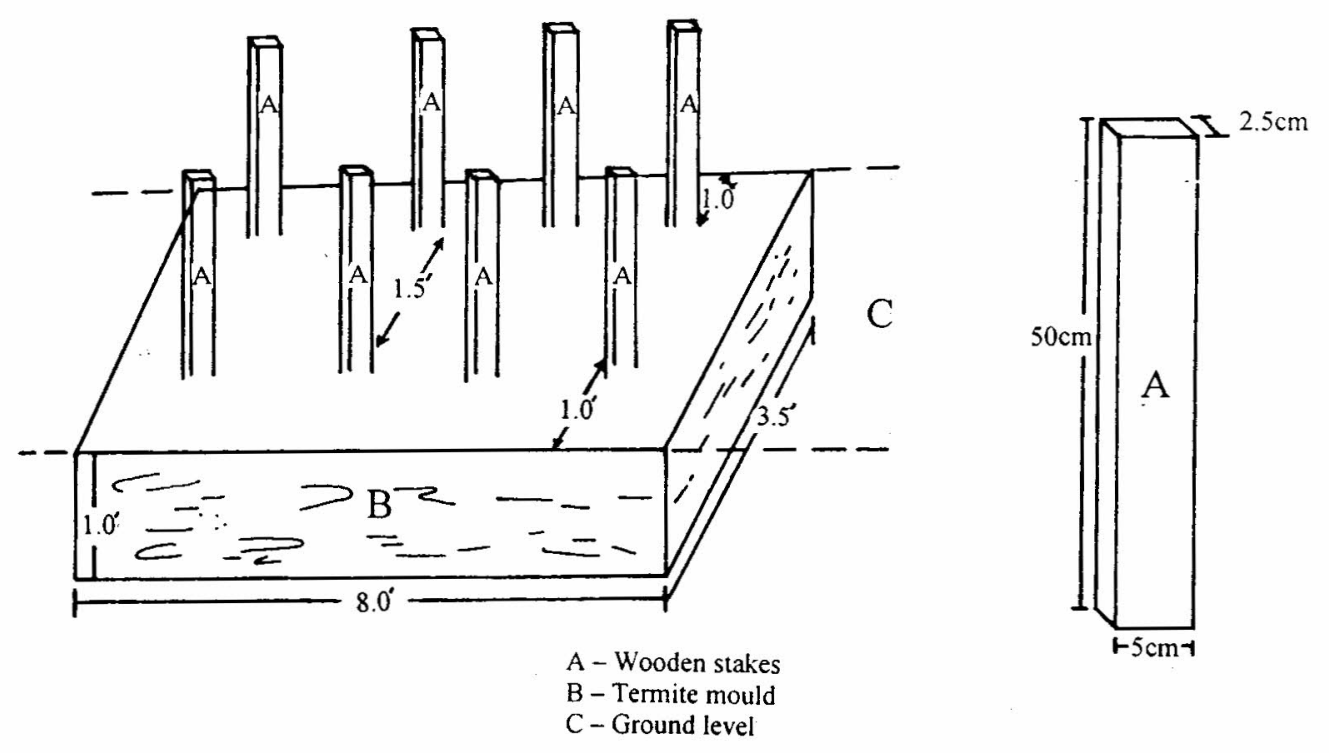

Figure 1: Grave yard Field test for testing subterranean termites 
Jars of $250 \mathrm{ml}$ capacity were used. Each jar jar contained $75 \mathrm{~g}$ of soil and $15 \mathrm{ml}$ of distilled water. Wooden wafers $2.5 \times 2.5 \times 0.2 \mathrm{~cm}$, of heartwood each test species, were placed on the soil. The jars were sealed with cotton plugs and aluminium foil and sterilized in the autoclave. Then 180 workers and 20 soldiers were put into each jar, under aseptic conditions (Figure 2). The weight loss of the wafers acording to the above equation was recorded after one month (Grace and Yamamoto, 1994)
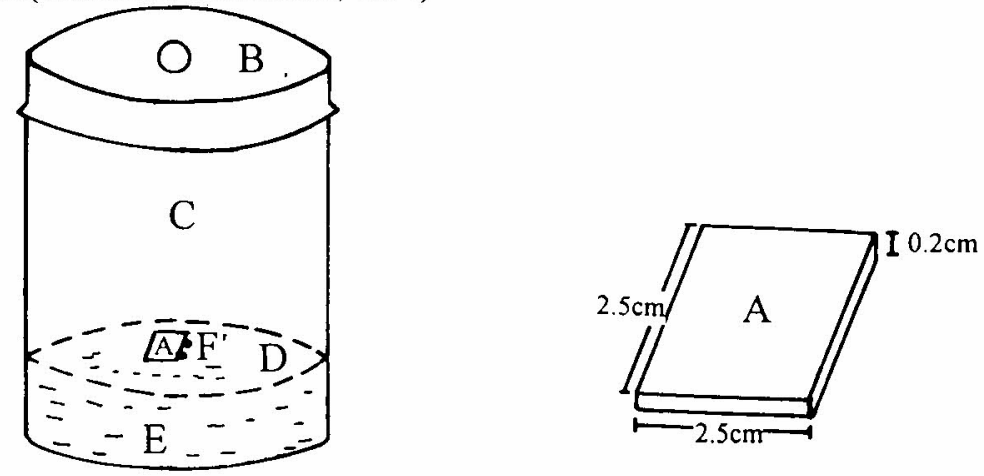

$$
\begin{aligned}
& \text { A - Wooden wafers } \\
& \text { B - Aluminium foil with cotton plug } \\
& \text { C - } 250 \mathrm{ml} \text { test jar } \\
& \text { D - } 180 \text { worker }+20 \text { soldier } \\
& \text { E - } 75 \mathrm{~g} \text {. soil }+15 \mathrm{ml} \text { distilled water } \\
& \text { F - Glass ring }
\end{aligned}
$$

Figure 2: Test jar apparatus used in the study of attack of subterranean termites in the laboratory

\section{Attack of pouder-post beetle}

A similar technique was used for the powder-post beetle, except that instead of wafers, wooden cubes of heartwood, $2.5 \times 2.5 \times 2.5 \mathrm{~cm}$, were used. The jars were bigger, $500 \mathrm{ml}$, and instead of soil, each contained $75 \mathrm{~g}$ of sawdust from the same timber species as the cube. Ten beetles were placed in each jar (Figure 3). Weight losses were recorded as for the termites (Eaton and Hale, 1993).

\section{Attack of longhorn bectle}

Freshly cut shor logs, two samples from each species, $30 \mathrm{~cm}$ in diameter and $30 \mathrm{~cm}$ in length, were used for this test. Tualang was not included, as no fresh logs were available. The test pieces were soaked in water for a week. Three holes $(1.5 \mathrm{~cm}$ in diameter and $7.5 \mathrm{~cm}$ in length) were drilled into each of them, one from bark to pith, one through the sapwood, and one into the heartwood (Figure 4). The logs were kept wet by covering them with constantly wetted filter paper. Longhorn beetle larvae (about $7.5 \mathrm{~cm}$ in length) were put in the holes, and left for one month. The weight losses were recorded. 
For all the experiments, observations were made on the mortality of the insects. The data on weight loss and mortality were analysed by ANOVA and Tukey's multiple comparison test.
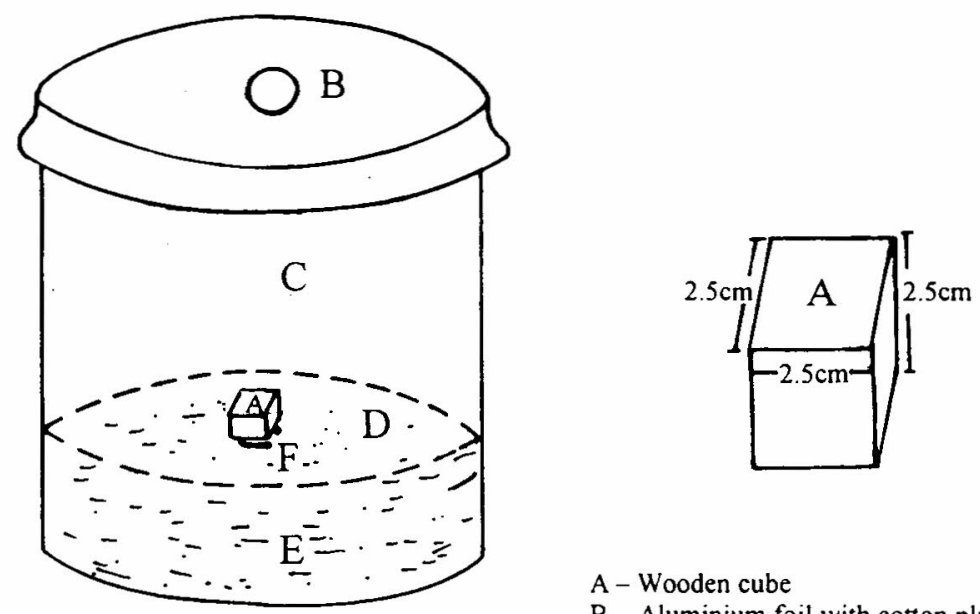

A - Wooden cube

B - Aluminium foil with cotton plug

C $-500 \mathrm{ml}$ test jar

D. 10 pinhole borer

E - Saw dust $+15 \mathrm{ml}$ distilled water

$\mathrm{F}$ - Glass ring

Figure 3: Test jar apparatus used in the study of attack of powder - post beetles

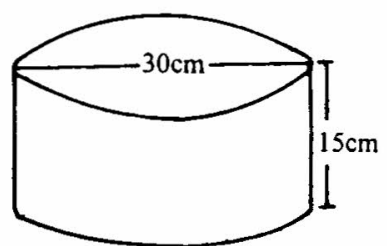

Log slice, before larvae were introduced

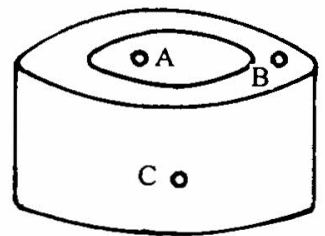

Log slice, after holes were drilled

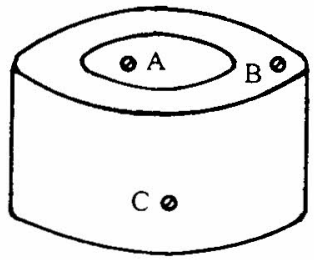

A - Hole through heard wood

B - Hole through sap wood

C - Hole from bark to pith

Figure 4: Log slices in which Longhorn Beetles (Betocera) lanae were introduce 


\section{Results and discussion}

In the graveyard test. the greatest weight loss was observed in rubber, and the second greatest in pine. indicating non-durability when exposed to subterrancan termites (Table 1). The weight loss in teak was negligible. confirming its high natural durability. In the laboratory test. termites fed on all species, but the weight losses were small $(<10 \%)$ for jak, tualang. teak. and cucalypts. Rubber was highly susceptible to termite attack in the laboratoty, as in the graveyard test (Table 2).

Table 1: Results of graveyard test

\begin{tabular}{lll}
\hline Species & $\begin{array}{l}\text { Site I \% Wt. loss } \\
\text { Mean } \pm \text { SD }\end{array}$ & $\begin{array}{l}\text { Sitc 2\%W1. loss } \\
\text { Mcan } \pm \text { SD }\end{array}$ \\
\hline teak & $0.025 \pm 0.035$ & 0 \\
cucalypt & $0.530 \pm 0.085$ & $0.140 \pm 0.113$ \\
tualiang & $0.580 \pm 0.721$ & $0.260 \pm 0.269$ \\
jak & $0.625 \pm 0.148$ & $0.460 \pm 0.651$ \\
lumumidilla & $5.150 \pm 0.552$ & $1.560 \pm 1.273$ \\
mahogany & $10.585 \pm 3.345$ & $20.750 \pm 10.960$ \\
pine & $29.545 \pm 0.771$ & $21.840 \pm 3.196$ \\
rubber & $35.695 \pm 4.151$ & $32.760 \pm 4.794$ \\
\hline
\end{tabular}

Table 2: Laboratory test for subterranean termites

\begin{tabular}{lll}
\hline Species & $\begin{array}{c}\text { \%Wt. loss } \\
\text { Meant } \pm \text { SD }\end{array}$ & $\begin{array}{c}\text { \%ortality } \\
\text { Main } \pm \text { SD }\end{array}$ \\
\hline jak & $3.8(0) \pm 0.5(1)$ & $21.5 \pm 2.12$ \\
lualang & $+.880 \pm 1.6(0)$ & $21.0 \pm 1.41$ \\
teak & $7.015 \pm 0.177$ & $18.0 \pm 1.41$ \\
eucalypt & $9.405 \pm 1.987$ & $15.5 \pm 0.71$ \\
pine & $10.815 \pm 3.981$ & $13.5 \pm 2.12$ \\
lunumidilla & $13.805 \pm 0.672$ & $12.0 \pm 1.41$ \\
malhogany & $15.390 \pm 0.552$ & $10.5 \pm 0.71$ \\
rubber & $2+.260 \pm 1.047$ & $6.0 \pm 1.41$ \\
\hline
\end{tabular}

Results for the powder-post beetle were different from those for termites. It did not feed on tualang. eucalypts, jak. or teak. Also. on these species. no insects survived (Table 3). malogany. on the other hand. was highly susceptible to powder-post beetle. and all the insects survived on this species. Higher susceptibility of malogany has been attributed to high starch content (Hoshim and Husscin. 1981).

For the longhom beetle. the greatest weight loss was observed in jak (Table t). Pine. cucalypt. mahogany, and rubber were only lightly attacked. All the introduced larvae died on all these wood species. Teak was only moderately attacked.

\section{2}


De Silva and Amarasekera

Table 3 : Laboratory test for powder-post bectle

\begin{tabular}{lll}
\hline Species & $\%$ Wt. loss Mean \pm SD & $\begin{array}{l}\% \text { Mortality } \\
\text { Mcan } \pm \text { SD }\end{array}$ \\
\hline tualang & 0 & 100 \\
cucalypt & 0 & 100 \\
jak & 0 & 100 \\
leak & 0 & 100 \\
rubber & $13.160 \pm 0.240$ & $10.0 \pm 0.0$ \\
lunumidilla & $15.830 \pm 0.849$ & 0 \\
pine & $15.900 \pm 0.651$ & $5.0 \pm 7.07$ \\
mahogany & $40.090 \pm 0.127$ & 0 \\
\hline
\end{tabular}

Table 4: Laboratory test for longhorn beetle

\begin{tabular}{lll}
\hline Species & $\begin{array}{c}\% \text { Wt. loss } \\
\text { Mcan } \pm \text { SD }\end{array}$ & $\begin{array}{l}\% \text { Mortality } \\
\text { Mean } \pm \text { SD }\end{array}$ \\
\hline tualang & $-\mathrm{b}$ & - \\
pines & $0.600 \pm 0.014$ & 100 \\
eucalypt & $0.940 \pm 0.000$ & 100 \\
malhogany & $0.940 \pm 0.014$ & 100 \\
rubber & $1.210 \pm 0.5(09$ & 100 \\
teak & $1.745 \pm 0.106$ & $83.5 \pm 23.3$ \\
lumumidilla & $6.655 \pm 0.021$ & 0 \\
jak & $7.980 \pm 0.028$ & 0 \\
\hline
\end{tabular}

Table 5: Relative resistance (durability) rating in different tests

\begin{tabular}{|c|c|c|c|c|c|c|}
\hline & (iraveyard & $\begin{array}{l}\text { Tenmiles } \\
\text { in lab. }\end{array}$ & $\begin{array}{l}\text { Powder-post } \\
\text { beetle in lab. }\end{array}$ & $\begin{array}{l}\text { Longlom } \\
\text { beetle in lab. }\end{array}$ & Total & $\begin{array}{l}\text { Overall } \\
\text { rating }\end{array}$ \\
\hline teak & 1 & 3 & 1 & 5 & 10 & 2 \\
\hline jak & 4 & 1 & 1 & 7 & 13 & 3 \\
\hline tualang & 3 & 2 & 1 & - & - & - \\
\hline emcalypt & 2 & 4 & 1 & 2 & 09 & 1 \\
\hline $\begin{array}{l}\text { malıoga } \\
\text { ny }\end{array}$ & 6 & 7 & 8 & 3 & 24 & 6 \\
\hline $\begin{array}{l}\text { lumunid } \\
\text { ella }\end{array}$ & 5 & 6 & 6 & 6 & 23 & 5 \\
\hline pine & 7 & 5 & 7 & 1 & 20 & 4 \\
\hline nubler & 8 & 8 & 5 & 4 & 25 & 7 \\
\hline
\end{tabular}




\section{Conclusions and recommendations}

The limbers were ranked according to their resistance to atlack (Table 5). Eucalypt was ranked number onc. followed by teak and jak. Durability rating for teak has become less than cucalyptus because teak was more susceptible to longhoria bectle attack. Eucalypt, teak and jak were the most resistance species to insect altack (Table 5). These three are reconmended for use in construction. exterior joinen. and furniture. Resistance of pinc. lunumiddella. and mahogany was lower than those three species. Rubber was ranked as number seven. It is recommended for use only after preservative treatment.

\section{References}

De Silva H S and Amarasekera H S (1996) Investigation of wood destroying insects in Sri Lanka in different climatic zones of Sri Lanka. Proceed dings of the Sixteenth. Inmual Se'sion of the Institute of Bioloy, Sir Lanka

Eaton R A and Hale M D C (1993) Hood decal, pests and protection. Chapman Hall. London

Gay F J. Greares T. Holdway F G and Wetherly A G (1957) The development techniques with termites in Australia. Bulletin No 280. 8 -30

Grace J K and Yamamoto R T (1994) Natural resistance of Alaska cedar. red wood and teak to Formosan subterranean tcrmites. Forest Products Journal $+4(3), 41-44$

Hoshim W S and Ho Y F (1993) Heterosbostrychus aequalis - A common powder - post beetle of timbers. FRIM Technical Information. No 42

Hussein N B T (1981) A preliminary assessment of the relative susceptablity of rubber wood to beetle infestation. The I Yalaysian Forester. $4+(4)$. $482-486$ 